Canadian Journal of Soil Science Revue canadienne de la science du sol

\title{
Comparison of Models for Predicting Pore Space Indices and their Relationships with CO2 and N20 Fluxes in a Corn- Soybean Field
}

\begin{tabular}{|r|l|}
\hline Journal: & Canadian Journal of Soil Science \\
\hline Manuscript ID & CJSS-2015-074.R2 \\
\hline Manuscript Type: & Special Issue Paper (Please select below) \\
\hline Complete List of Authors: & $\begin{array}{l}\text { Panday, Dinesh; Lincoln University, Agriculture and Environmental Sciences } \\
\text { Nkongolo, Nsalambi; Lincoln University of Missouri, Agriculture and } \\
\text { Environmental Sciences; Institut Facultaire des Sciences Agronomiques } \\
\text { (IFA) de Yangambi, Departement de Sol et Eau }\end{array}$ \\
\hline Keywords: & Air Capacity, Greenhouse gas, Porosity, Soil quality, Soil structure \\
\hline \multicolumn{2}{|c}{} \\
\hline
\end{tabular}


Comparison of Models for Predicting Pore Space Indices and their Relationships with $\mathrm{CO}_{2}$ and $\mathrm{N}_{2} \mathrm{O}$ Fluxes in a Corn-Soybean Field

\author{
Dinesh Panday ${ }^{1}$ and Nsalambi V. Nkongolo ${ }^{2,3 *}$
}

${ }^{1}$ Department of Soils, Environmental and Atmospheric Sciences, University of MissouriColumbia, Columbia, MO 65201, USA; ${ }^{2}$ Department of Agriculture and Environmental Sciences, Lincoln University of Missouri, Jefferson City, MO 65101, USA; ${ }^{3}$ Institut Facultaire des Sciences Agronomiques (IFA-Yangambi), BP 1232 Kisangani, Republique Democratique du Congo

*Corresponding author: nkongolo@lincolnu.edu 


\section{ABSTRACT}

Several models predict soil pore space indices (the relative gas diffusion coefficient, $\mathrm{D}_{\mathrm{s}} / \mathrm{D}_{\mathrm{o}}$ and the pore tortuosity, $\tau$ ), but information is lacking on which models predicted indices better relate to soil processes. We compared pore space indices predictive models based on air-filled porosity $\left(f_{\mathrm{a}}\right)$ alone vs models using air-filled porosity and total pore space $(\Phi)\left(f_{\mathrm{a}}+\Phi\right)$. We also assessed the relationships between these indices and $\mathrm{CO}_{2}$ and $\mathrm{N}_{2} \mathrm{O}$. The study was conducted from 2011 to 2014 on a silt loam soil at Lincoln University. Soil samples were collected at 0-10 and 10-20 $\mathrm{cm}$ depth and oven dried at $105^{\circ} \mathrm{C}$ for $72 \mathrm{~h}$. After drying, $f_{\mathrm{a}}$ and $\Phi$ were calculated, and later used in models for predicting $\mathrm{D}_{\mathrm{s}} / \mathrm{D}_{\mathrm{o}}$ and $\tau . \mathrm{CO}_{2}$ and $\mathrm{N}_{2} \mathrm{O}$ were measured with a Shimadzu Gas Chromatograph (GC) and a Photoacoustic Gas Analyzer (PSA). Results showed that $\mathrm{D}_{\mathrm{s}} / \mathrm{D}_{\mathrm{o}}$ predicted using $f_{\mathrm{a}}$ alone (Marshall and Buckingham) was higher as a compared to values predicted with models based on $f_{\mathrm{a}}+\Phi$ (Sallam et al, Millington, and Jin and Jury) $(\mathrm{p}<0.001)$. However, values of $\tau$ predicted with models based on $f_{\mathrm{a}}$ alone were lowest $(\mathrm{p}<0.001) . \mathrm{CO}_{2}$ and $\mathrm{N}_{2} \mathrm{O}$ measured with GC better related with $\mathrm{D}_{\mathrm{s}} / \mathrm{D}_{\mathrm{o}}$ and $\tau$.

Keywords: Soil pore structure, diffusivity models, gas diffusion coefficient, pore tortuosity factor, greenhouse gases emissions 


\section{INTRODUCTION}

Most climate scientists agree that the prime cause of the current global warming trend is the expansion of the greenhouse effect. It originates mainly from anthropogenic activities including land use and land use change in agricultural and forest systems, industrial development and urban expansion, among other sources (Lambin et al., 2003). It results into more emissions of greenhouse gases (GHGs) such as carbon dioxide $\left(\mathrm{CO}_{2}\right)$, methane $\left(\mathrm{CH}_{4}\right)$, nitrous oxide $\left(\mathrm{N}_{2} \mathrm{O}\right)$, troposphere ozone $\left(\mathrm{O}_{3}\right)$ and chlorofluorocarbons (CFCs) (Fletcher et al., 2012; IPCC, 2013). In soil, these GHGs are mainly emitted through soil pore under microbiological processes and their flux variations are regulated by processes which control microbial activities (Nkongolo et al., 2010a).

Porosity is an index of the relative pore space in a soil (Hillel, 1998; Negassa et al., 2015). The gas diffusion and the tortuosity properties of pore space are collectively called as soil pore space indices (Nkongolo et al., 2010a). The soil gas diffusion coefficient $\left(\mathrm{D}_{\mathrm{s}} / \mathrm{D}_{\mathrm{o}}\right)$ and its dependency on air-filled porosity $\left(f_{\mathrm{a}}\right)$ govern most gas diffusion processes in soil (Ungureanu and Statescu, 2010), whereas the pore tortuosity factor $(\tau)$ is a quantity which characterizes the convoluted nature of the porous pathways followed by diffusing species (Hudson and Aharonson, 2008).

Gas diffusion in porous media is a fundamental topic and there are numerous predictive models that describe soil diffusivity processes for undisturbed soils in the vadose zone (Zheng et al., 2012). However, information is still lacking on which models' predicted indices relate better to soil processes. For instance, some models are based only air-filled porosity $\left(f_{\mathrm{a}}\right)$ and are linear in nature, some are a combination of air-filled porosity and total pore space $\left(f_{\mathrm{a}}+\Phi\right)$, and non-linear, some uses soil water curve, etc. Nkongolo et al (2010b) have predicted the relative gas diffusion coefficient $\left(\mathrm{D}_{\mathrm{s}} / \mathrm{D}_{\mathrm{o}}\right)$ either as a function of air-filled porosity $\left(f_{\mathrm{a}}\right)$ alone: 
$\mathrm{D}_{\mathrm{s}} / \mathrm{D}_{\mathrm{o}}=f_{\mathrm{a}}^{1.5}$ (Marshall, 1957)

$\mathrm{D}_{\mathrm{s}} / \mathrm{D}_{\mathrm{o}}=f_{\mathrm{a}}^{2}$ (Buckingham, 1904)

or as a quotient of air-filled porosity $\left(f_{\mathrm{a}}\right)$ over total porosity $(\Phi)$ :

$\mathrm{D}_{\mathrm{s}} / \mathrm{D}_{\mathrm{o}}=f_{\mathrm{a}}{ }^{3.1} / \Phi^{2}$ (Sallam et al., 1984)

[3]

$\mathrm{D}_{\mathrm{s}} / \mathrm{D}_{\mathrm{o}}=f_{\mathrm{a}}^{3.33} / \Phi^{2}$ (Millington, 1959)

$\mathrm{D}_{\mathrm{s}} / \mathrm{D}_{\mathrm{o}}=f_{\mathrm{a}}{ }^{2} / \Phi^{2 / 3}($ Jin and Jury, 1996)

In addition, Nkongolo et al (2010b) also predicted the pore tortuosity factor $(\tau)$ as either a function of air-filled porosity $\left(f_{\mathrm{a}}\right)$ alone:

$$
\begin{aligned}
& \tau=1 / f_{\mathrm{a}}{ }^{0.5}(\text { Marshall, 1957) } \\
& \tau=1 / f_{\mathrm{a}}(\text { Buckingham, 1904) }
\end{aligned}
$$

or as a quotient of total porosity $(\Phi)$ over air-filled porosity $\left(f_{\mathrm{a}}\right)$ :

$$
\begin{aligned}
& \tau=\Phi^{2} / f_{\mathrm{a}}^{2.1} \text { (Sallam et al., 1984) } \\
& \tau=\Phi^{2} / f_{\mathrm{a}}^{2.33} \text { (Millington, 1959) } \\
& \tau=\Phi^{2 / 3} / f_{\mathrm{a}}(\text { Jin and Jury, 1996) }
\end{aligned}
$$

Besides soil temperature and moisture (Davidson and Trumbore, 2002), indices of N availability (Kim and Dale, 2008), only a few authors have focused on $\mathrm{D}_{\mathrm{s}} / \mathrm{D}_{\mathrm{o}}$ and $\tau$ as potential controlling factors for GHGs emissions. Hence, the objectives of this study were (i) to compare pore space indices predictive models based on air-filled porosity $\left(f_{\mathrm{a}}\right)$ alone vs models using air-filled porosity and total pore space $\left(f_{\mathrm{a}}+\Phi\right)$, and (ii) to assess the relationships between pore space indices and greenhouse gas emissions $\left(\mathrm{CO}_{2}\right.$ and $\left.\mathrm{N}_{2} \mathrm{O}\right)$ in a corn and soybean field. 


\section{MATERIALS AND METHODS}

\section{Experimental field}

The study was conducted from 2011 to 2014 at Freeman farm of Lincoln University of Missouri (Fig. 1) on a Waldron silt loam soil (Fine, smectitic, calcareous, mesic Aeric Fluvaquents) with an average slope of 2 percent. The coordinates of the experimental site are $38^{\circ} 34^{\prime} 55.8^{\prime \prime} \mathrm{N}$, $92^{\circ} 06 ' 26.9^{\prime \prime} \mathrm{W}$. The average annual temperature and precipitation of those 4 years during the crop growing season were given in Fig. 2 and Fig. 3 respectively.

The experiment field consisted of 16 plots of $12.19 \mathrm{~m}$ width by $21.34 \mathrm{~m}$ length for each, arranged in randomized complete block with 3 replicates for a total of 48 experimental units. The treatments were (i) tillage at 2 levels (no tillage vs conventional tillage), (ii) cover crop at 2 levels (rye vs no-rye) and (iii) cropping sequence or rotation at four levels (continuous corn, continuous soybean, corn-soybean and soybean-corn rotations). All the plots received 26.31: 67.25: $89.67 \mathrm{~kg} / \mathrm{ha}$ NPK. Additional nitrogen in the form of urea was applied to all corn plots at the rate of $201.75 \mathrm{~kg} / \mathrm{ha}$

\section{Soil sampling and greenhouse gases measurements}

Soil sampling and GHGs measurements protocols for this study were reported in Kladivko et al. (2014). Basically, soil samples were collected at two depths $(0-10$ and 10-20 cm) at 3 locations in the field, using a core sampler with a volume $384.65 \mathrm{~cm}^{3}$ for a total number of 288 samples. They were collected after planting and full emergence of the seeds. After drying $\left(105^{\circ} \mathrm{C}\right.$ for 72 h), bulk densities (BD), air-filled porosity $\left(f_{\mathrm{a}}\right)$ and total pore space $(\Phi)$ were calculated. The relative gas diffusion coefficient $\left(D_{s} / D_{0}\right)$ and the pore tortuosity factor $(\tau)$ were thereafter predicted using diffusivity models described earlier. $\mathrm{CO}_{2}$ and $\mathrm{N}_{2} \mathrm{O}$ were measured using a 
Shimadzu Gas Chromatograph (GC-2014) in 2011 and 2012 while a Photoacoustic Gas Analyzer (PSA) was used in 2013 and 2014. For GC-2014 measurements (2011 and 2012), soil air samples for gas analysis were collected using 48 individual PVC static and vented chambers of $30 \mathrm{~cm}$ height and $20 \mathrm{~cm}$ diameter. Chambers were installed in each plot throughout the growing season and air samples were collected during every two weeks using a $60 \mathrm{ml}$ syringe and stored in a $200 \mathrm{ml}$ Tedlar bag. The concentrations of $\mathrm{CO}_{2}$ and $\mathrm{N}_{2} \mathrm{O}$ from air samples were measured using a GC-2014 within 2 hours of collection. For the photoacoustic method (2013 and 2014), $\mathrm{CO}_{2}$ and $\mathrm{N}_{2} \mathrm{O}$ were measured only in 16 plots belonging either corn-soybean rotation or soybeancorn rotation (Fig.1). Seven measurements were taken from each plot with a two minutes interval between each measurement and the concentration (average from 7 measurements) was recorded in database. The data was then transferred into an Excel data sheet where the gas concentrations were converted to a flux value (e.g. $\mathrm{mg} \mathrm{C}-\mathrm{CO}_{2} \mathrm{~m}^{-2} \mathrm{~h}^{-1}$ ).

\section{Statistical analysis}

Statistix 10.0 software was used to analyze data. Log10 transformation was applied to 2014 soil for diffusivity models. Treatments effect on measured variables were tested by analysis of variance (ANOVA), and comparisons among treatment means were made using the least significant difference (LSD) multiple range test calculated at $\mathrm{p}<0.05$. Factorial AOV was used to assess the relationship between treatment combinations, compared using Means and Standard error functions, and later plotted on graphs. Pearson correlation and linear regression analysis were used to assess the relationship between soil pore space indices and greenhouse gas fluxes. 


\section{RESULTS}

\section{Pore space indices predictive models}

\section{Relative gas diffusion coefficient $\left(\mathrm{D}_{\mathrm{s}} / \mathrm{D}_{\mathbf{0}}\right)$}

The summary of statistics (Table 1 ) for the relative gas diffusion coefficient $\left(D_{S} / D_{o}\right)$ measured from 2011 to 2014 showed that the Marshall model predicted the highest $\mathrm{D}_{\mathrm{s}} / \mathrm{D}_{\mathrm{o}}$ values for all the 4 years of this study. The Marshall model also had the lowest coefficient of variation (CV) in 2011 and 2014. The Jin and Jury model was next with high values of $D_{s} / D_{o}$ and low CV in 2012 and 2013. A pair wise comparison for $D_{s} / D_{o}$ (Table 2) showed that all diffusivity models were significantly different regardless of the predictive model $(\mathrm{p}<0.001)$.

\section{Pore tortuosity factor}

Overall, the summary statistics for $\tau$ showed lowest mean values in Marshall (Table 3). However, the highest mean was observed in the Millington model. A pair wise comparison of models (Table 4) showed that all diffusivity models were significantly different for the pore tortuosity factor $(\tau)$ predicted using either $f_{\mathrm{a}}$ alone or a combination of $f_{\mathrm{a}}+\Phi$ models $(\mathrm{p}<0.0001)$

\section{Greenhouse gases fluxes}

Tables 5 and 6 show that emissions of $\mathrm{CO}_{2}$ and $\mathrm{N}_{2} \mathrm{O}$ from experimental plots where were highest in 2011 and 2012 than rest of the years. $\mathrm{CO}_{2}$ fluxes were highest in 2011 while $\mathrm{N}_{2} \mathrm{O}$ fluxes in 2012. The highest emissions of $\mathrm{CO}_{2}$ ranged from $62.67 \mathrm{mg} \mathrm{C}-\mathrm{CO}_{2} \mathrm{~m}^{-2} \mathrm{~h}^{-1}$ (conventional tillage, rye crop, corn- soybean rotation) to $457.9 \mathrm{mg} \mathrm{C}-\mathrm{CO}_{2} \mathrm{~m}^{-2} \mathrm{~h}^{-1}$ (conventional tillage, no rye crop, continuous soybean). $\mathrm{N}_{2} \mathrm{O}$ emissions in 2012 ranged from $25.33 \mu \mathrm{g} \mathrm{N}-\mathrm{N}_{2} \mathrm{O} \mathrm{m} \mathrm{m}^{-1}$ (continuous 
tillage, no rye crop, soybean-corn rotation) to $302.72 \mu \mathrm{g} \mathrm{N}-\mathrm{N}_{2} \mathrm{O} \mathrm{m}{ }^{-2} \mathrm{~h}^{-1}$ (conventional tillage, no rye crop, corn-soybean rotation).

\section{Relationship between pore space indices and $\mathrm{CO}_{2}$ and $\mathrm{N}_{2} \mathrm{O}$ fluxes}

In 2012, there was a positive correlation between $\mathrm{CO}_{2}$ and $\mathrm{Ds} / \mathrm{Do}(\mathrm{r}=0.49, \mathrm{p}<0.05)$ as showed in Fig. 4 while Fig. 5 shows that $\mathrm{CO}_{2}$ was negatively correlated with $\tau(\mathrm{r}=-0.42, \mathrm{p}<0.05)$. In 2013, however, this trend changed with $\mathrm{CO}_{2}$ negatively correlating with Ds/Do $(\mathrm{r}=0.51, \mathrm{p}<0.05)$ and $\tau$ positively correlating with $\mathrm{CO}_{2}(\mathrm{r}=0.55, \mathrm{p}<0.05)$. In $2012, \mathrm{~N}_{2} \mathrm{O}$ was significantly correlated with Ds/Do $(\mathrm{r}=0.36, \mathrm{p}<0.05)($ Fig. 6) and $\tau(\mathrm{r}=0.32, \mathrm{p}<0.05)$ (Fig. 7). There was no significant correlation between $\mathrm{N}_{2} \mathrm{O}$ and Ds/Do and $\tau$ in 2013 and 2014.

\section{DISCUSSION}

The Marshall diffusivity model (based on $f_{\mathrm{a}}$ ) predicted both the highest $\mathrm{D}_{\mathrm{s}} / \mathrm{D}_{\mathrm{o}}$ and lowest tortuosity. This is understandable as this model is linear and uses a lower power to compute $\mathrm{D}_{\mathrm{s}} / \mathrm{D}_{\mathrm{o}}$ and $\tau$ from $f_{\mathrm{a}}$. There was less emission of $\mathrm{CO}_{2}$ in 2011 as compared to 2012,2013 and 2014. One possible reason behind less emissions of $\mathrm{CO}_{2}$ in 2011 is the increase in $\mathrm{N}$ fertilization which generally decreases soil $\mathrm{CO}_{2}$ emissions (Halvorson et al. 2002; Micks et al. 2004; Wilson and Al-Kaisi, 2008).

$\mathrm{N}_{2} \mathrm{O}$ emissions were also highest in 2012. The possible reason for higher emissions in 2012 than rest of the other years could be due to the drought. In fact, in 2012 , temperature was up to $29.2^{\circ} \mathrm{C}$ during crop growing period. Soil temperature and moisture strongly influence not only the $\mathrm{N}_{2} \mathrm{O}$ production by the activity of microorganisms (Signor and Cerri, 2013), but also its diffusion to the atmosphere (Davidson and Swank, 1986). Liu et al. (2011) reported that $\mathrm{N}_{2} \mathrm{O}$ emissions 
exponentially increased with increasing soil temperatures $\left(0-50^{\circ} \mathrm{C}\right)$. This explains the existence of a close relationship among seasonal variation of $\mathrm{N}_{2} \mathrm{O}$ flux and soil and air temperatures (Wolf and Brumme, 2002; Zhang and Han, 2008).

In 2011 and 2013, negative $\mathrm{N}_{2} \mathrm{O}$ fluxes were also observed which means uptake or consumption of $\mathrm{N}_{2} \mathrm{O}$. Low mineral $\mathrm{N}$ and large moisture contents have sometimes been found to favor $\mathrm{N}_{2} \mathrm{O}$ consumption. Generally, the conditions interfering with $\mathrm{N}_{2} \mathrm{O}$ diffusion in the soil seem to enhance $\mathrm{N}_{2} \mathrm{O}$ consumption (Lydie et al., 2007). Pore space indices were correlated with greenhouse gases, however the nature of the relationship changed from year to year as it was the case for $\mathrm{CO}_{2}$ vs $\mathrm{D}_{\mathrm{s}} / \mathrm{D}_{\mathrm{o}}$ which correlated positively in 2012 , but negatively in 2013 . Weltecke and Gaertig (2010) and Nan et al (2016) also reported negative correlations between $\mathrm{CO}_{2}$ and the gas diffusion coefficient $\left(\mathrm{D}_{\mathrm{s}} / \mathrm{D}_{\mathrm{o}}\right)$. Nan et al (2016) found a significant negative correlation between $\mathrm{CO}_{2}$ concentrations and the diffusion gas coefficient from 0 to $20 \mathrm{~cm}$ and a significant positive correlation from 40 to $100 \mathrm{~cm}$ depth of soil. They attributed this phenomenon to more rapid production and efflux of soil $\mathrm{CO}_{2}$ from 0 to $20 \mathrm{~cm}$. In fact, it has been suggested that $\mathrm{CO}_{2}$ transport may be limited due to a decrease in the effective diffusion coefficient with increasing soil moisture (Jassal et al., 2004; Fang and Moncrief, 1999). Obviously, the 40-100 cm soil layer had more moisture. In our study, we noticed that $D_{s} / D_{0}$ generally decreased from 2011 to 2014 , but also $\mathrm{CO}_{2}$ emissions decreased from 2012 to 2013. This might have caused the shift in the direction of the relationship between $\mathrm{CO}_{2}$ and $\mathrm{D}_{\mathrm{s}} / \mathrm{D}_{\mathrm{o}}$. Other authors have also reported the existence of the relationships between pore space indices and greenhouse gases emissions (Nkongolo et al., 2010b) and hence inclusion of Ds/Do and $\tau$ in predictive models will certainly improve our understanding of the dynamics of greenhouse gas fluxes from soil. 


\section{ACKNOWLEDGEMENTS}

This research is part of a regional collaborative project supported by the USDA-NIFA, Award No. 2011-68002-30190, Cropping Systems Coordinated Agricultural Project: Climate Change, Mitigation, and Adaptation in Corn-based Cropping Systems. Project Website: http://sustainablecorn.org.

\section{REFERENCES}

Buckingham, E. 1904. Contributions to Our Knowledge of the Aeration of Soils. Bulletin 25. U.S. Dep. Agric. Bereau of Soils Bulletin. 25: 52 pp

Davidson, E.A. and Swank, W.T. 1986. Environmental Parameters Regulating Gaseous Nitrogen Losses from 2 Forested Ecosystems via Nitrification and Denitrification. Applied and Environmental Microbiology. 52 (6): 1287-1292.

Davidson, E.A. and Trumbore, S.E. 2002. Gas Diffusivity and Production of $\mathrm{CO}_{2}$ in Deep Soils of the Eastern Amazon. Tellus B. 47 (5): 550-565.

Fang, C., Moncrief, J.B. 1999. Amodel for soil $\mathrm{CO}_{2}$ production and transport 1: Model development. Agric. Forest Meteorol. 95: 225-236.

Fletcher, C., Abrams, M., Ibrahim, S., Musa, S. and Kassim, A.R. 2012. Beyond the Red Meranti: Fresh Perspectives on Malaysia's Pasoh Forest and Climate Change. Forest Research Institute, Malaysia. [Online] Available: http://test.scripts.psu.edu/faculty/a/g/agl/Pasoh\%20Book\%20.pdf [2015 Jul. 26].

Jassal, R.S., Black, T.A., Drewitt, G.B., Novak, M.D., Gaumont-Guay, D., Nesic, Z. 2004. A model of the production and transport of $\mathrm{CO} 2$ in soil: predicting soil $\mathrm{CO}_{2}$ concentrations and $\mathrm{CO}_{2}$ efflux from a forest floor. Agric. Forest Meteorol. 124:219-236. 
Halvorson, A.D., Del Grosso, S.J. and Alluvione, F. 2009. Nitrogen Rate and Source Effects on Nitrous Oxide Emissions from Irrigated Cropping Systems in Colorado. Better Crops with Plant Food. 93 (1):16-18.

Halvorson, A.D., Wienhold, B.J. and Black, A.L. 2002. Tillage, Nitrogen, and Cropping System Effects on Soil Carbon Sequestration. Soil Sci. Soc. Am. J. 66: 906-912.

Hillel, D. 1980. Fundamentals of Soil Physics. Academic press, Orlando, FL.

Hudson, T.L. and Aharonson, O. 2008. Diffusion Barriers at Mars Surface Conditions: Salt Crusts, Particle Size Mixtures, and Dust. J. of Geophysical Research. 13 (9): 1991-2012.

IPCC. 2013. Climate Change 2013: The Physical Science Basis. Intergovernmental Panel on Climate Change Working Group. [Online] Available: http://www.climatechange2013.org/ [2016 Feb. 10].

Jin, Y. and Jury, W.A. 1996. Characterizing the dependency of gas diffusion coefficient on soil properties. Soil Sci. Soc. Am. J. 60: 66-71.

Kim, S., and Dale, B.E. 2008. Effect of Nitrogen Fertilizer Application on Greenhouse Gas Emissions and Economics of Corn Production. Environ. Sci. Technol. 15 (42): 6028-6023.

Kladivko E. J., Helmers M. J., Abendroth L. J., Herzmann D., Lal R., Castellano M. J., Mueller D. S., Sawyer J. E., Anex R. P., Arritt R. W., Basso B., Bonta J. V., Bowling L. C., Cruse R. M., Fausey N. R., Frankenberger J. R., Gassman P. W., Gassmann A. J., Kling C. L., Kravchenko A., Lauer J. G., Miguez F. E., Nafziger E. D., Nkongolo N. V., O'Neal M., Owens L. B., Owens P. R., Scharf P., Shipitalo M. J., Strock J. S., and Villamil M. B. 2014. Standardized research protocols enable transdisciplinary research of climate variation impacts in corn production systems. Journal of Soil and Water Conservation, 69 (6): 532 542. 
Lambin, E.F., Geist, H.M. and Lepers, E. 2003. Dynamics of Land-use and Land-cover change in Tropical regions. Annual review of Environmental and Resources. 28: 205-241.

Liu, C., Wang, K., Meng, S., Zheng, X., Han, S., Chen, D. and Yang, Z. 2011. Effects of Irrigation, Fertilization and Crop Straw Management on Nitrous Oxide and Nitric Oxide Emissions from a Wheat-maize Rotation Field in Northern China. Agriculture, Ecosystems and Environment. 140 (1-2): 226-233.

Lydie, C.L, Wrage, N., Metay, A., Chotte, J. and Bernoux, M. 2007. Soils, a sink for $\mathrm{N}_{2} \mathrm{O}$ ? A review. Global Change Biology. 13 (1): 1-17.

Marshall, T.J. 1957. Permeability and size distribution of pores. Nature (London). 180: 664-665.

Micks, P., Aber, J.D., Boone, R.D. and Davidson, E.A. 2004. Short Term Soil Respiration and Nitrogen Immobilization Response to Nitrogen Applications in Control and NitrogenEnriched Temperate Forests. For. Ecol. Manage. 196: 57-70.

Millington, R.J. 1959. Gas Diffusion in Porous Media. Science. 130: 100-102.

Nan, W., Yue, S., Li, S., Huang, H., Shena, Y. 2016. The factors related to carbon dioxide effluxes and production in the soil profiles of rain-fed maize fields. Agriculture, Ecosystems and Environment. 216: 177-187

Negassa, W. C., Guber, A. K., Kravchenko, A. N., Marsh, T. L., Hildebrandt, B. and Rivers, M. L. 2015. Properties of Soil Pore Space Regulate Pathways of Plant Residue Decomposition and Community Structure of Associated Bacteria. PLoS ONE. 10 (4), e0123999. doi:10.1371/journal.pone.0123999.

Nkongolo, N.V., Johnson, S., Schmidt, K. and Eivazi, F. 2010a. Greenhouse Gases Fluxes and Soil Thermal Properties in a Pasture in Central Missouri. J. Env. Sci. 22 (7): 1029-1039. 
Nkongolo, N.V., Hatano, R. and Kakembo, V. 2010b. Diffusivity Models and Greenhouse Gases Fluxes from a Forest, Pasture, Grassland and Corn field in Northern Hokkaido. Pedosphere. 20 (6): 747-760.

Sallam, A., Jury, W.A. and Letey, J. 1984. Measurement of Gas Diffusion Coefficient under Relatively Low Air-filled Porosity. Soil Sci. Soc. Am. J. 48: 3-6.

Signor, D. and Cerri, C.E.P. 2013. Nitrous Oxide Emissions in Agricultural Soils: A Review. Pesq. Agropec. Trop. 43 (3): 322-338.

Ungureanu, A. and Statescu, F. 2010. Models for Predicting the Gas Diffusion Coefficient in Undisturbed Soil. Tom. 55 (69): 168-172.

Weltecke, K. and Gaertig, T. 2010. Soil aeration deficiencies in urban sites. Geophysical Research Abstracts, Vol. 12, EGU2010-194

Wilson, H.M., and Al-Kaisi, M.M. 2008. Crop Rotation and Nitrogen Fertilization Effect on Soil $\mathrm{CO}_{2}$ Emissions in Central Iowa. Applied Soil Ecology. 39: 264-270.

Wolf, I. and Brumme R. 2002. Contribution of Nitrification and Denitrification Sources for Seasonal $\mathrm{N}_{2} \mathrm{O}$ Emissions in an Acid German Forest Soil. Soil Biology \& Biochemistry. 34 (5): 741-744.

Zhang, J. and Han, X. 2008. $\mathrm{N}_{2} \mathrm{O}$ Emission from the Semiarid Ecosystem under Mineral Fertilizer (urea and superphosphate) and increased Precipitation in Northern China. Atmospheric Environment. 42 (2): 291-302.

Zheng, Q., Yu, B., Wang, S., and Luo, L. 2012. A Diffusivity Model for Gas Diffusion through Fractal Porous. Chemical Engineering Science. 68 (1): 650-655. 